\title{
Is Global Management of Anti-Global Warming Policies at All Feasible?
}

\author{
Jan-Erik Lane \\ Correspondence: Jan-Erik Lane, emeritus professor at UNIGE, Switzerland. \\ Received: May 21, 2018 Accepted: June 19, 2018 Online Published: July 10, 2018 \\ doi:10.11114/bms.v4i3.3435 URL: https://doi.org/10.11114/bms.v4i3.3435
}

\begin{abstract}
Climate and earth scientists now predicting abrupt climate change never ask the social sciences whether large scale policy-making and international coordination, like the COP21 project, is all feasible. The message from policy analysis is that rational decision-making is a myth, as there is bound to be mistakes, confusion and opportunism in policy implementation. Is it better for each state to develop its own climate policy - the resilience option? However, when looking at energy planning by core states, one finds little of decarbonisation. Only Uruguay has good preparation for global warming. Abrupt climate change threatens numerous tipping points towards Hawking irreversibility. But the social sciences are skeptical about large scale policy implementation based upon comprehensively rational decisionmaking.
\end{abstract}

Keywords: COP21 project, rational decision-making, policy implementation, global coordination abrupt climate change

\section{Introduction}

It is emphasized by the natural sciences that the increase in the greenhouse gases (GHG) in Earth' atmosphere is due to human causes, as the emission of GHGs from nature has remained stable since the start of the industrial revolution. Several kinds of GHGs exist, but the UNFCCC has concentrated upon the CO2s in their coordination efforts to halt GHG increases in the COP21 project. Other GHGs like for instance methane and NO2 are more potent in their greenhouse effect, but occur in less quantity today.

Global government coordination has come so far that the UN has enacted the policy objective of almost complete decarbonisation in this century at the COP21 reunion in Paris 2015. But can this formidable objective to be managed? Let us consult the social sciences concerning big policy implementation as well as about international coordination.

Can the increase in GHGs be stopped before the so-called Hawking irreversible point, where climate chaos become unstoppable? To ponder about the question, so fatal for humanity, we need a theory about what is achievable by policymaking and international coordination.

\section{Policy and Management: Climate Chaos or Economic Crisis?}

As we get more and more dire predictions about the nature of climate change and its probable consequences, it becomes more and more urgent to clarify what the COP project can and must accomplish. Climate change could be halted by a sharp reduction in the use of fossil fuels over night, but it would spell large scale economic crisis with mass unemployment and social upheaval.

Many climate experts now claim that we are heading for more than a +2 Celsius increase in global warming as well as already a +2 Celsius augmentation is a threat to human survival due to the many positive feedback loops started by such an increase. As the doomsday scenarios gather strength, it becomes absolutely vital to stick to the COP project and explore what can be achieved and how.

The overall objective of the COP21 project from Paris 2015 is to start decarbonisation by 2020 and finish it by 2075. A necessary condition is that states conduct energy policies that eliminate coal and start solar power parks. This requires enormous management skills by individual governments with support from global coordination agencies or committees. A drastic policy tool is carbon sequestration or capture, but it is hardly viable at the moment.

Climate engineering may add to the basic means: abolition of coal and big solar power parks.

\section{Logic of Policy Implementation or Management}

The debate about big project implementation or management was initiated by Max Weber around 1900, suggesting his 
means-end framework:

"All serious reflection about the ultimate elements of meaningful human conduct is oriented primarily in terms of the categories "end" and "means." We desire something concretely either "for its own I sake" or as a means of achieving something else which is more highly desired. The question of the appropriateness of the means for achieving a given end is undoubtedly accessible to scientific analysis. Inasmuch as we are able to determine (within the present limits of our knowledge) which means for the achievement of a proposed end are appropriate or inappropriate, we can in this way estimate the chances of attaining a certain end by certain available means. "(Weber, 1922, 1949: 54-55)

According to Weber, human behaviour is to be understood by an inquiry into the intention or motivation, a mental concept that is decomposed into means and ends. An action is rational when an actor decides upon the most effective means for realising his/her goals by enhancing outcomes. This teleological mode of analysis fit humans especially, as they haw the mental capacity to calculate. Often an end when fulfilled is a means to a further goal, i.e. we have meansend chains.

Do such intentions - means-end chains - work in the sense of rationality or effectiveness? Rational decision-making excludes unrealistic objectives and errors in the calculation of means. The COP21 project is an example of rational decision-making where mankind is the supposed actor:

a) End: halting global warming at $+1,5$ or 2 degrees Celsius;

b) Means: decarbonisation, achieved around 2075;

c) Intermediate means: i) stopping the increase in $\mathrm{CO} 2 \mathrm{~s}$ in 2020 ;

ii) reducing $\mathrm{CO} 2 \mathrm{~s}$ totally by around $30 \%$ up to 2030 ; iii) voluntary approach by each state with weak oversight but economic assistance from a Super Fund.

Does the Paris 2015 satisfy the criteria of rational decision-making, namely: realistic objectives, consistent preferences, correct causal belief in the relationship between means and outcomes, maximisation of probability $\mathrm{X}$ utility over all alternatives and outcomes? The main schools of policy implementation and management have replied as follows.

\section{Bounded rationality (H. Simon)}

Simon would have had no difficulties in rejecting the COP21 project as not fitting the rational decision-model. He would point out the cognitive limitations in the project:

a) No comprehensiveness: COP21 bypasses one major GHG, namely mathane. If lots of methane are released in the Arctic, COP21 will fail no mater what;

b) Ambiguity of objectives: what is the sense of "decarbonisation" when no specific targets are set in absolute numbers that are observable and verifiable?

c) Absence of control mechanisms like oversight, incentives (positive or negative) and mere promises without sanctions.

Simon argues that only bounded rationality or restricted decision-making is feasible, both for single individuals and organisations or groups. Especially organisations pursue "standard operating procedures", according to March, meaning simplifications of the requirements of full rationality, as laid down by the neo-classical decision model in economics. As a matter of fact, the arrival of abrupt climate change makes the COP21 project already outdated.

\section{Implementation gap (Wildavsky)}

Scholars with the discipline of public administration follow the teachings of A. Wildavsky about an inescapable gap between policy ex ante and implementation ex post. Implementation theory was developed for national policy-making with finding of a major gap between blue-prints in the centre and implementation failure at the local or regional levels. Policy-makers engaging in nation wide programs face bounded rationality. Thus, each and every national policy includes uncertainty and has to be adapted or changed locally.

The same policy - implementation gap applies to international relations where coordination efforts are not only hampered by bounded rationality but also the restrictions from public international law, especially the principle of state sovereignty.

The COP21 Treaty may have been a great leap forward from one point of view, namely environmentalism as philosophy, but the entire COP21 project face enormous implementation difficulties, as policies are vague and management lacking.

\section{Organised chaos (March and Olsen)}

In the theory of organisations, one has been very interested in the possibility of groups of people to engage in rational action, like the governments of the world setting up a plan for global decarbonisation. The answer is that individual 
rationality may be feasible at the micro level, but large organisations with many decision-makers must fail at the macro level. There will be simply too much conflict, confusion, mistakes, lack of consistency over time ${ }^{-}$in one word chaos. In organised collective action, leadership is luck, preferences changing and information biased.

Judging the COP21 Treaty from the perspective of March and Olsen, launching their conception of government as organised chaos, one may have serious doubts about the implementation of the COP21 project. A promise is made of giant money in a Super Fund, but how to fund it? Global decarbonisation is set out in three main stages, but it is a too slow process with many loopholes. And the conflicts among states are deep concerning which countries should do the most and contribute the most to the Super Fund.

\section{Reneging or cheating}

Even if one accepts that the COP21 project is rational or semi-rational decision-making (clear preferences, reasonable technology), game theory would warn that it is wide open to strategic behaviour and asymmetric information. It does not matter it is micro level or macro level choice, as both individual and collective decision-making can be cheated upon by reneging upon promises.

The COP21 Treaty is nothing but a paper with promises for a very long time and with enormous practical consequences. Why deliver upon it? Energy transformation is costly and affect ordinary people. When costs go up, maybe defect from promises made a time ago? Or demand a hefty compensation from the Super Fund?

The paradox of the famous PD game lies at the core of the COP21 project. It is rational for each single participant in the common pool regime (CPR) to defect hoping that the others will deliver (N-1 problem) or to delay contributing because the benefits will be shared by others (1/N problem). The US has already reneged because the Trump administration does not to contribute to the Super Fund or India's decarbonisation costs. As the COP21 project moves along, there will be many opportunities for defection, especially as the PIL sanctions this.

\section{International society versus anarchy of states}

The COP21 Agreement enters public international law, when it has been ratified by the UN member states. Scholars have held great hopes about the PIL, restraining state sovereignty. But it is only forcing governments when it comes to the questions of war and peace, where the Security Council rules if unanimous. Rule of rule in an international society has not yet accomplished, meaning that several treaties of PIL can be reneged upon, like the COP21 Treaty. Governments tend to first and foremost act upon national interests, even when it foes against international norms.

Why in the first place is there such an enormous demand for energy, especially during recent decades?

\section{Energy Demand in a Wide Sense}

I suggest we analyse energy in a wide sense. The need for energy is obvious in all the human sources of GHGs - see Figure 1.

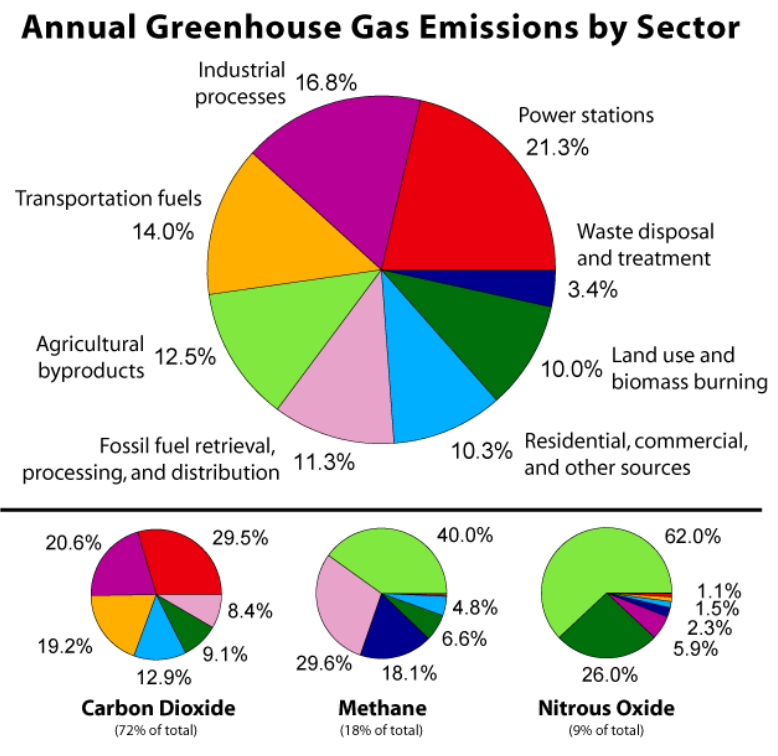

Figure 1. Human sources of GHGs, globally

Source: https://en.wikipedia.org/wiki/Climate_change_mitigation 
What Figure 1 shows is that the GHGs stem from all vital sectors of society, not merely energy production itself must be underlined that GHG emissions are a function of GDP and population. Only very big poor countries have huge GHG emissions, like India, Brazil and Indonesia. Small poor nations have little GHGs, as they lack energy in great quantity. Yet, poor countries wish to participate in saving the planet from the dangers of climate change on the condition of financial assistance from the COP project and its Super Fund.

Yet, energy is the capacity to do work. And work is the source of human welfare. The growth in energy consumption since the industrial revolution and especially after the Second World War has been just immense, especially the supply of fossil fuels. In poor countries, the demand for energy is huge for economic development, whereas rich countries are heavily dependent of fossil fuels for economic growth. Why demand for energy when resulting in so much $\mathrm{CO} 2 \mathrm{~s}$ ?

\section{Positive Consequences of Energy Access}

The majority of countries in the COP project are in poverty, as they need more energy. Thus, they can only decarbonise when renewable energy sources become available. This is the redistribution task of COP21.

The living conditions in the poor countries in Latin America, Africa and Asia as well as the Pacific reflects the low level of energy employed. This basic fact determines life opportunities in a most dramatic fashion. The low access to energy has consequences for the environment and the life situation of people, including health, schooling, work, food and potable water.

African countries are poor because they have too little energy. Thus, they have much less GHGs than Asia. Yet, they need the COP project of the UNFCCC to renew their energy sources and move from fossil fuels and traditional renewables to solar power. Hydro power depends upon water availability that shrinks with global warming.

African energy deficit is conducive to a dire environment with enormous damages and risks. Consider the following global figures. Figure 2 shows how low energy leads to am unsafe environmental.

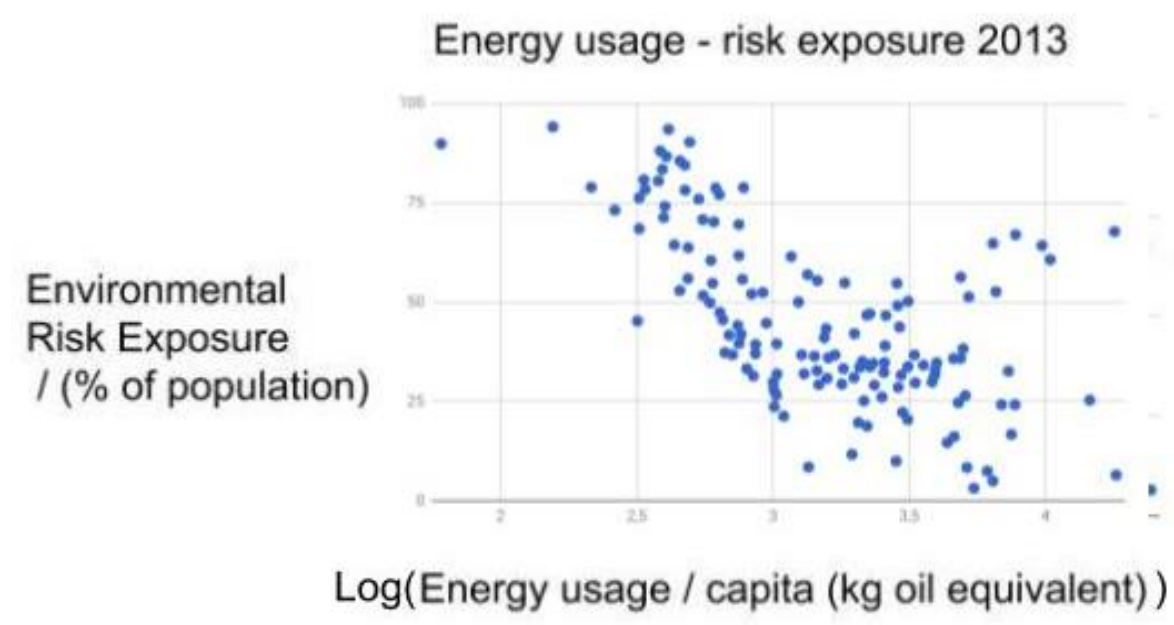

Figure 2. Energy and environmental risk exposure

Source: Environmental Performance Index, Yale University, https://epi.envirocenter.yale. IEA Statistics @ OECD/IEA 2014 (http://www.iea.org/stats/inde

Low energy use leads to poverty, malnutrition, deceases, lack of potable water, insufficient sanitation, etc. Typical of many Latin American, African and Asian nations is the lack of stable electricity, which hampers everything and reduces environmental viability. Figure 3 has the global picture. 


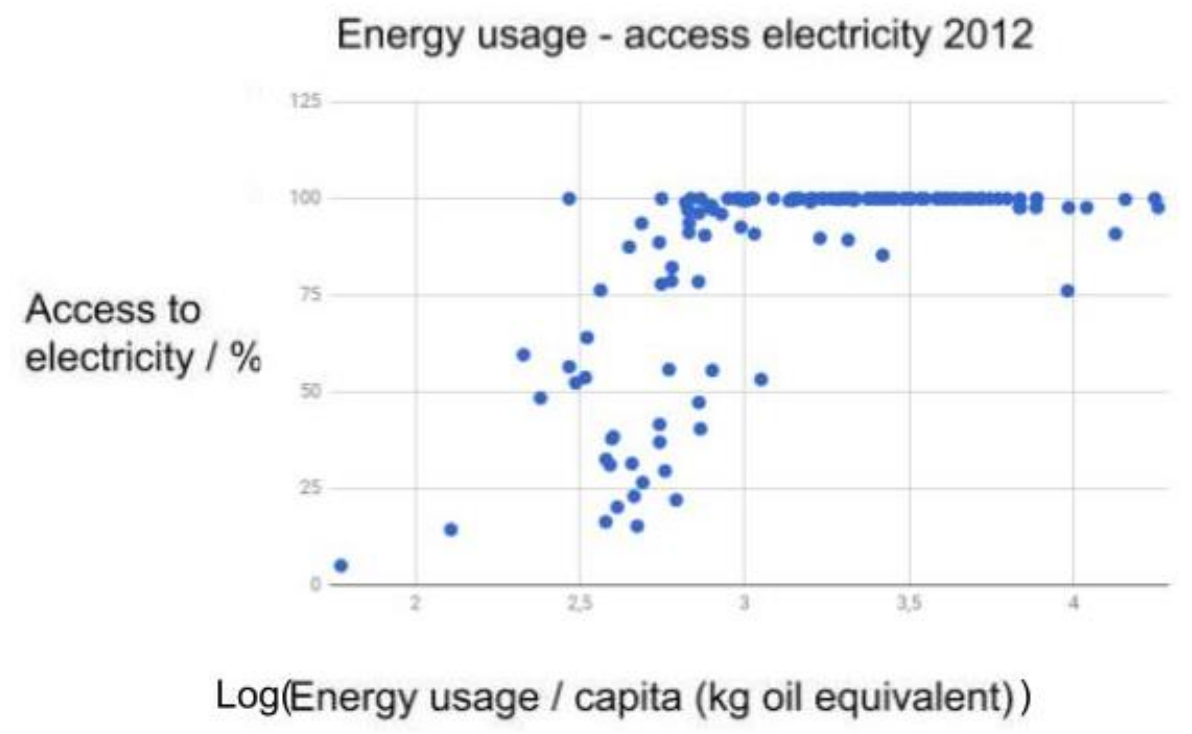

Figure 3. Energy and electricity access

Source: Environmental Performance Index, Yale University, https://epi.envirocenter.yale. IEA Statistics @ OECD/IEA 2014 (http://www.iea.org/stats/inde)

The access to safe and stable electricity is crucial for health, schools, food, water, etc. Figure 4 links energy with proper sanitation.

\section{Energy usage - access sanitation 2014}

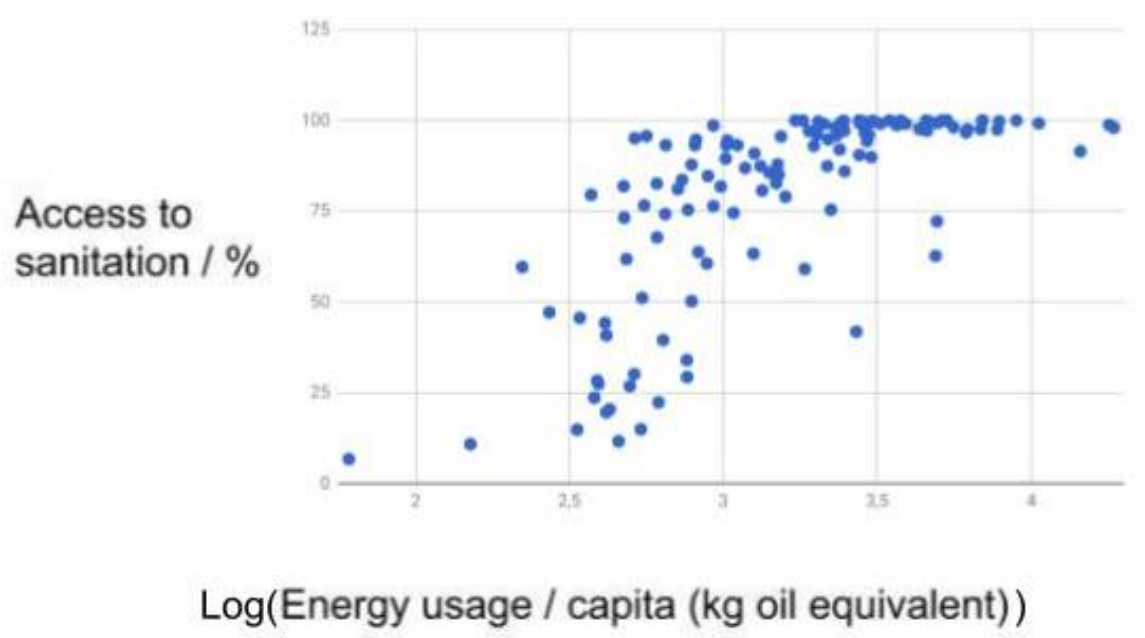

Figure 4. Sanitation and energy

Source: Environmental Performance Index, Yale University, https://epi.envirocenter.yale. IEA Statistics () OECD/IEA 2014 (http://www.iea.org/stats/index)

Especially, the rapidly growing African and Asian mega-cities lack entirely sewage plants. Thus, dirty water is put into the big rivers where other cities downstream take their potable water.

The access to safe and stable electricity is crucial for health, schools, food, water, etc.

Figure 4 links energy with proper sanitation.

Figure 5 underscores the necessity of more energy in poor coutries. 


\section{Energy usage - unsafe sanitation 2014}

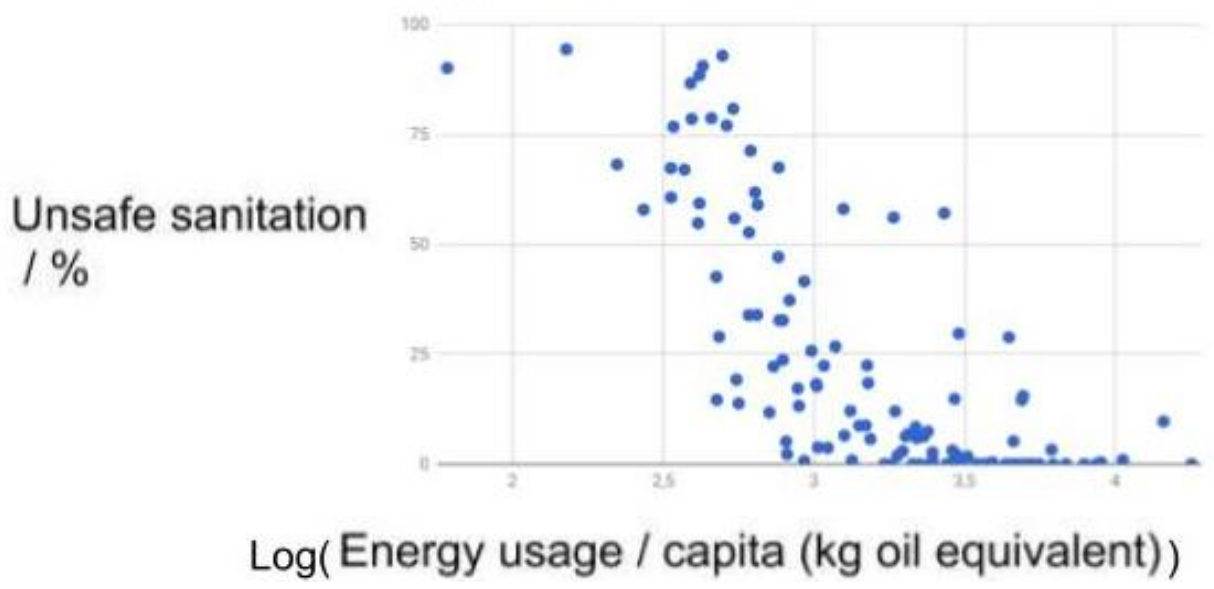

Figure 5. Energy and unsafe sanitation

Source: Environmental Performance Index, Yale University, https://epi.envirocenter.yale. IEA Statistics @ OECD/IEA 2014 (http://www.iea.org/stats/inde

Air quality too depends upon energy access (Figure 6).

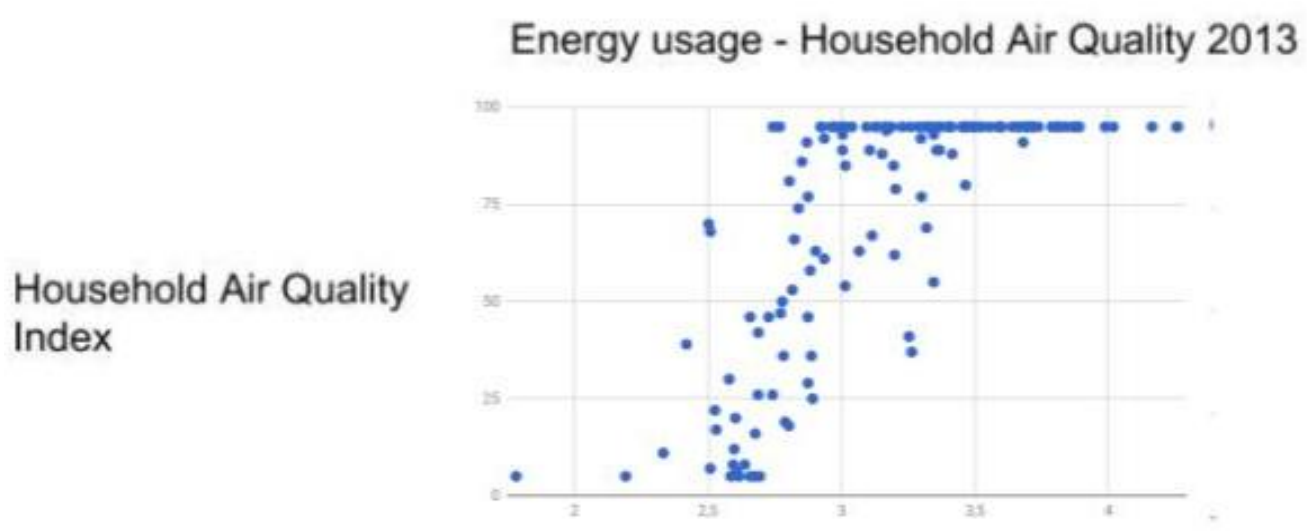

Log(Energy usage / capita (kg oil equivalent))

Figure 6. Energy and air quality

Source: Environmental Performance Index, Yale University, https://epi.envirocenter.yale. IEA Statistics @ OECD/IEA 2014 (http://www.iea.org/stats/inde)

Typical of many poor nations - Latin America, Africa, Asia - is the lack of stable electricity, which hampers work and reduces environmental viability. The access to safe electricity is crucial for health, schools, food, water, etc. Given the lack of enough energy in poor countries being conducive to the above bad living conditions, one understands the hopes of the poor countries for help with energy transformation leading to better access to just energy

In terms of GHGs, rich countries have much higher levels of yearly emissions compared with poor countries, holding population constant. Only when a poor has an enormous population is it a big CHG polluter.. Strict linear relation hold between GDP, energy consumption

If, as we believe, energy consumption is behind global warming, the set of poor countries face a most difficult dilemma. On the one hand, they can demand much more energy like fossil fuels, but they then contribute much to climate change, On the other hand, global warming while fabricated by the rich nations and a few very populous poor nations, will have very negative consequences for poor nations. The only way out of this dilemma is that all countries contribute to halting global warming by turning to renewables, especially the set of rich countries. 
Thus, energy consumption is closely related to country affluence. The poor countries can only improve living condition by increase energy supply. Their energy demand can only go up, because energy supply is highly skewed to the advantage of the rich countries - see Figure 7.

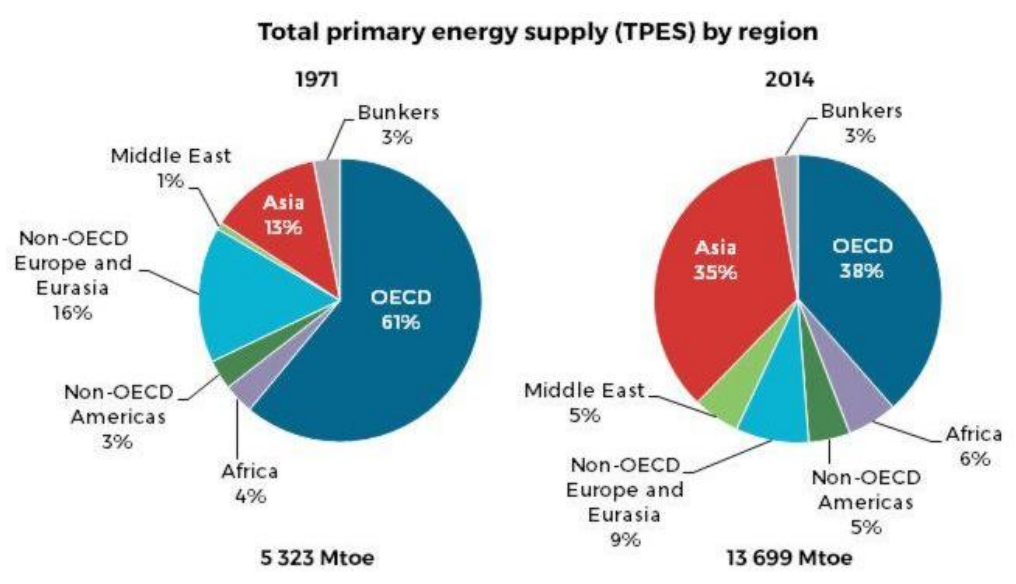

Figure 7. Global Energy Consumption

Source: https://www.iea.org/newsroom/news/2016/august/iea-data-shows-global-energy-production-and-consumptioncontinue-to-rise.html

Poor countries need much more energy, but of a new kind. They need assistance to move to modern renewables, as they will give up fossil fuel only if there is compensation by other new energy sources. Let us take a few examples of energy planning for the future by core states. Can they handle the consequences of climate change by themselves - the resilience strategy, advocated by disbelievers in global coordination.

\section{Can Resilience Work?}

Let us explore below whether the key countries are moving or planning to move in this decarbonisation direction? Each single country has its energy consumption pattern that must be taken into account in both domestic and international energy supply transformation.

India

In Indian energy policies, it is emphasized that developmental goals take precedence over climate change considerations. Thus, all Indian household must have access to electricity and only sustained rapid economic growth can reduce poverty. India has a "take-off" economy that delivers affluence for the first time since independence. But it is based on fossil fuels. India looks into other sources of energy, as long as socio-economic development is not hindered. Figure 8 shows the main features of future planning.

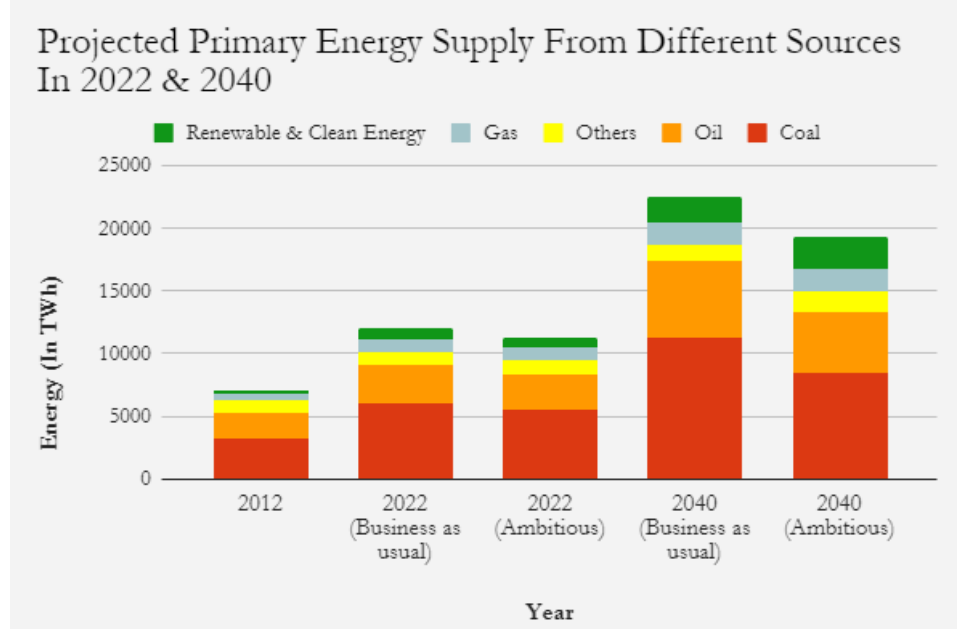

Figure 8. India`s energy future

Source: https://scroll.in/article/843981/indias-new-energy-policy-draft-projects-coal-fired-capacity-will-double-by2040-is-that-feasible 
India has rapidly become a major CO2 emitter due to its high growth rates since 1990. It uses lots of coal, stone or wood. Charcoal is bad for households and results in forest destruction. India tries to broaden its energy supply to modern renewables, like solar, wind and hydro power. Yet, it will remain stuck with fossil fuels for decades. It needs assistance from the COP21 project, especially for solar power parks. Building more dams is very risky, as global warming reduces water assets. Figure $\mathrm{X}$ indicates the India cannot meet its COP21 promises.

Brazil

Brazil is a "catch-up" with its "take-off" point long ago in the 20th century.. Compared with India, but it never really succeeds to close the gap to North America, tumbling now and then into dictatorship or recession. Figure Y shows its stylised energy plans - are they in agreement with COP21 hopes of decarbonisaton?

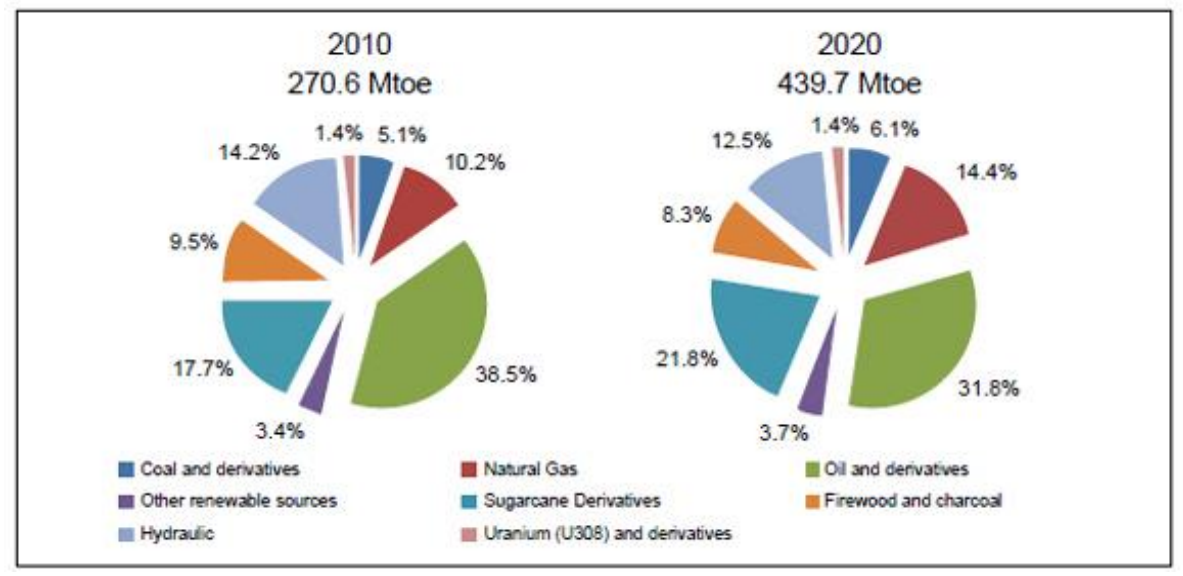

Figure 9. Energy plans in Brazil

Source: http://www.scielo.br/scielo.php?pid=S0103-40142012000100017\&script=sci_arttext\&tlng=en

Brazil has already a diversified supply of energy. However, since the country plans to almost double its energy supply, its dependence upon fossil fuel will grow, also upon coal. It dreams about building many more dams in the Amazons, but future water shortages due to climate change may make these plans unrealistic. The country needs COP21 assistance to turn to solar power massively, in order to eliminate first and foremost coal and charcoal. The rain forest is part of Brazil's emission picture where burning and logging reduce its carbon uptake.

Indonesia

Indonesia is like India a "take-off" country, enjoying rapid economic growth with attending augmentation in energy consumption. The outcome is that this giant nation has quickly become a major GHG emitter. What make the situation worse is the burning down of the rain forest in parts of Indonesia.

\section{INDONESIA'S NEW \& RENEWABLE ENERGY TARGET}

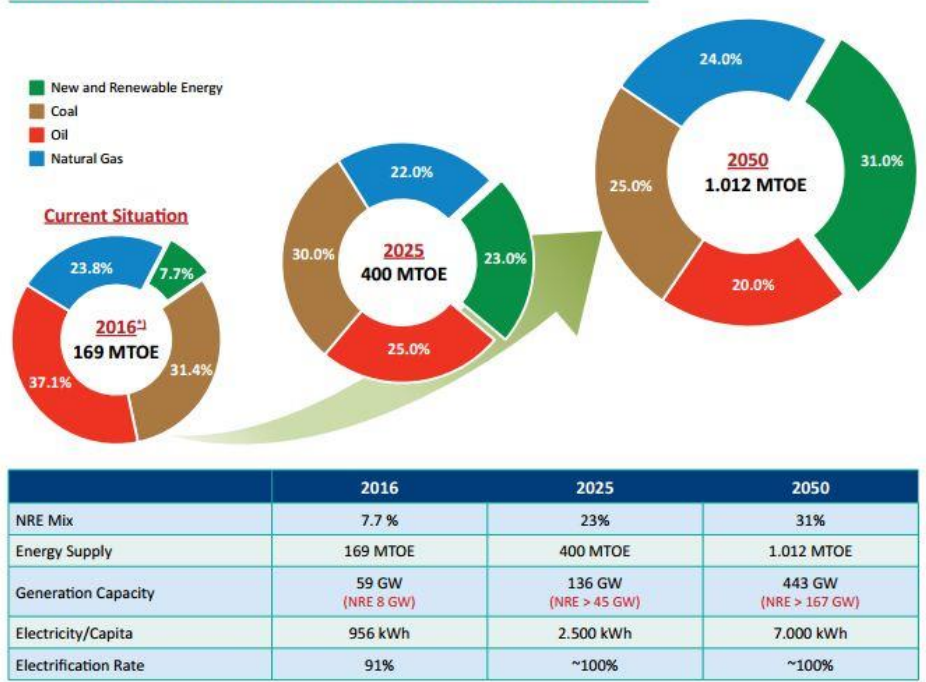

Figure 10. Energy future for Indonesia 
Indonesia`s energy augmentation plan is way beyond global decarnnisation plans.

USA

The US has reduced its $\mathrm{CO} 2$ emissions during the lats years, mainly by a shift to natural gas. Actually, several mature economies have been able to halt the rise of $\mathrm{CO} 2$ emissions, either by more energy efficiency or a shift to natural gas or renewables. Figure 11 captures some features in US energy plans.
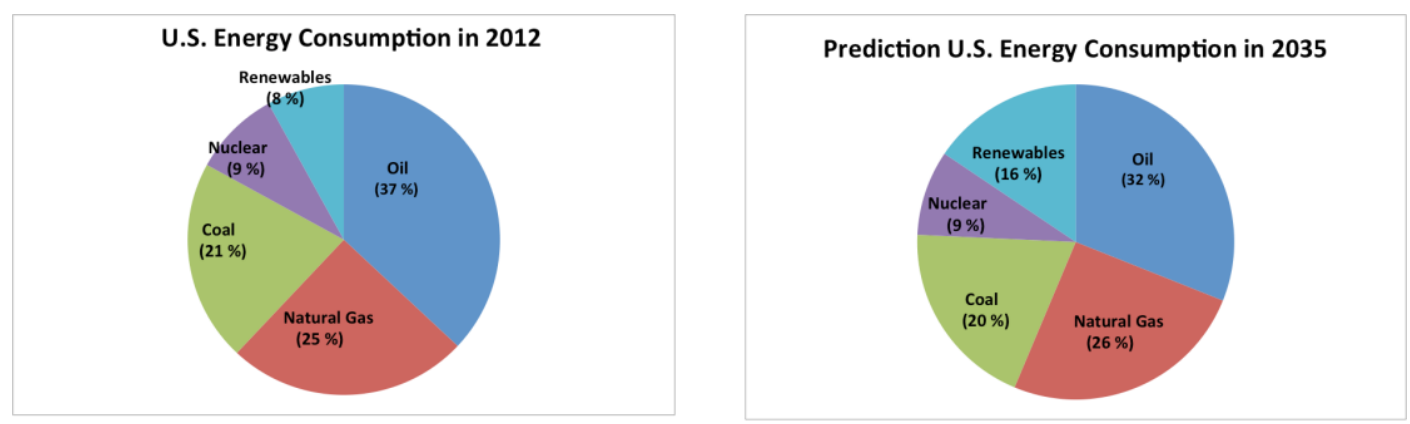

Figure 11. US energy future

Source: https://www.e-education.psu.edu/egee102/node/1930

Although the Figure 12 predicts a doubling of renewable energy, the dependency upon fossil fuels, including coal energy, will not bee much reduced. We are talking here about relative numbers, but if the US increases total amount of energy supply, then there may even be more fossil fuels. The reduction in CO2s during recent years seems to be coming at a reduced rate. The hope is for economic growth without energy increases, but we are not there yet. And most countries demand more energy for the future.

China now enters the First World, as it has long passed its "take-off" point in time around 1980 and has pursued a successful "catch-up" policy for a few decades. Its energy consumption, especially fossil fuels, has skyrocketed with GDP, resulting in the largest CO2 emission globally. Figure 12 has a projection for China.

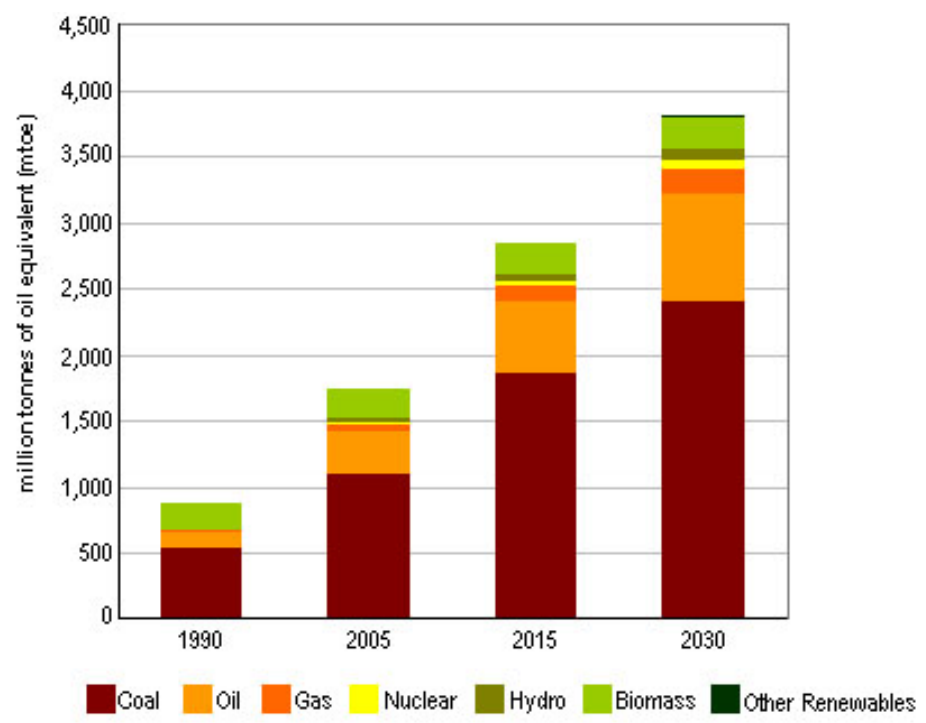

Figure 12. Energy projection for China

http://www.wrsc.org/attach_image/chinas-projected-energy-growth-fuel

Decarbonisation does not seem highly probable. Much hope was placed at a recent reduction in $\mathrm{CO} 2 \mathrm{~s}$, but water shortages forced China to revert to coal in 2017 with attending augmentation of CO2s. China is investing in both renewables and atomic power, but it also plans for large energy increase in the coming decades with lots of energy consuming new projects.

Resilience is not a promising option, as countries plan for much more supply of energy. Although each country needs to develop a decarbonisation strategy, involving the crucial steps in the necessarily giant energy transformation from fossil fuels to renewables, given the most recent information available about energy and its presuppositions, the COP 21 
secretariat could be helpful in designing the best projects and come up with cheap funding avenues, guaranteeing loans below market rates. It could make recommendation about carbon tax and renewable energy subsidies. Resilience is not a promising strategy against global externalities like the immense feedback lopes from global warming. It may end up in defection.

\section{The New Climate Debate: "Already Too Late"}

Among some climate scientists, there is recently a new urgency. The melting of the North polar ice is advancing so quickly that all projections about temperature rise on the Earth must be revised upwards. Quicker warming sets in motion very positive feedback $s$ that threaten human survival. The goal of COP21 - limit global warming to +2 degrees Celsius - is no longer achievable. Instead, climate chaos seems more likely. A few predict that mankind has no more than 10 years before things become unmanageable. When the North pole ice is gone, global warming goes much higher than +2 .

The theory that climate change is now becoming irreversible is based on new hypotheses concerning the consequences of global warming:

- sea level rise and Arctic ice meltdown is quicker than believed;

- climate refugees may rise to 100 million people;

- food and water shortages come earlier than believed;

- the +2 degrees Celsius target is misplaced as the Earth warms differently at various regions, i.e. still much hotter at the poles;

- the release of methane from the permafrost and the frozen ice at the North pole will bring temperature rise to +10 degrees Celsius;

- the COP21 policy is too slow and uncertain.

As the potentially huge methane emissions enter the climate change debate, one fully understands the mounting pessimism. And the entire time scale for fighting global warming shrinks considerably, from 100 years to 50 years or even less.

Yet, only improved COP21 policy-making could help. The Keeling must be stabilised as soon as possible, having reached 412 recently. The release of methane depends upon that. Thus, one may outline a more radical COP21 policy and ask for its implementation to start now:

1) Close down of all coal power plants in 2020; replacement of charcoal in poor countries by mini gas stoves;

2) Massive investments in solar power parks - see below; subsidies for solar installations in private homes;

3) Accelerated experiments with carbon capture to find accurate cost-benefit calculation.

Here comes the solar power revolution that will allow a massive reduction in fossil fuels. Let us see what it entails in terms of management tasks for global coordination, assisted by for instance the COP21 Secretariat and the IPCC.

Table 1. Number of Ouarzazate plants for 40 per cent reduction of CO2 in some giant countries (Note: Average of 250 300 days of sunshine used for all entries except Australia, Indonesia, and Mexico, where 300 - 350 was used).

\begin{tabular}{llll}
\hline \multicolumn{1}{c}{ Nation } & $\begin{array}{c}\text { Co2 reduction pledge / } \\
\text { \% of } \mathbf{2 0 0 5} \text { emissions }\end{array}$ & $\begin{array}{c}\text { Number of gigantic } \\
\text { solar plants needed } \\
\text { (Ouarzazate) }\end{array}$ & $\begin{array}{c}\text { Gigantic plants needed } \\
\text { for 40 \% reduction }\end{array}$ \\
\hline United States & $26-28$ & 2100 & 3200 \\
China & none & 0 & 3300 \\
EU28 & $41-42$ & 2300 & 2300 \\
India & none & 0 & 600 \\
Japan & 26 & 460 & 700 \\
Brazil & 43 & 180 & 170 \\
Indonesia & 29 & 120 & 170 \\
Australia & $26-28$ & 130 & 190 \\
Russia & none & 0 & 940 \\
World & N/A & N/A & 16000 \\
\hline
\end{tabular}

Note: i) The United States has pulled out of the deal; ii) No absolute target; iii) Pledge is above current level, no reduction; iv) Upper limit dependent on receiving financial support; v) EU joint pledge of $40 \%$ compared to 1990.

It will of course be argued against such a 40 per cent speedy reduction in $\mathrm{CO} 2 \mathrm{~s}$ that it leads to economic recession. So may it be! But it would reduce future much higher costs. After all, economies adapt and will recover due to all new investments needed in a decarbonised world. Ramesh (2015) emphasizes that India needs much economic assistance for decarbonisation - a giant task for global coordination to assist poor nations! 
Let us look at the American scene in Table 2.

Table 2. Number of Ouarzazate plants necessary for 40 per cent reduction in CO2 (Note: Average of 250 - 300 days of sunshine per year was used for Canada, 300 - 350 for the others).

\begin{tabular}{llll}
\hline Nation & $\begin{array}{c}\text { Co2 reduction pledge / } \\
\text { \% of 2005 emissions }\end{array}$ & $\begin{array}{c}\text { Number of gigantic } \\
\text { solar plants needed } \\
\text { (Ouarzazate) }\end{array}$ & $\begin{array}{c}\text { Gigantic plants needed } \\
\text { for 40 \% reduction }\end{array}$ \\
\hline Canada & 30 & 230 & 300 \\
Mexico & 25 & 120 & 200 \\
Argentina & none & 0 & 80 \\
Peru & none $^{11}$ & 0 & 15 \\
Uruguay & none & 0 & 3 \\
Chile & 35 & 25 & 30 \\
\hline
\end{tabular}

Note: i) The United States has pulled out of the deal; ii) No absolute target; iii) Pledge is above current level, no reduction; iv) Upper limit dependent on receiving financial support; v) EU joint pledge of $40 \%$ compared to 1990.

Some Latin American countries have lots of hydro power, but it may dwindle rapidly due to abrupt climate change. Solar power would be excellent energy for Mexico and Brazil for example.

Table 3 has the data for the African scene with a few key countries, poor or medium income. As they are not in general energy consuming on a grand scale, like Asia, decarbonisation should be feasible with Super Fund support.

Table 3. Number of Ouarzazate plants necessary in 2030 for 40 per cent reduction in CO2 (Note: Average of $300-350$ days of sunshine per year was used).

\begin{tabular}{llll}
\hline \multicolumn{1}{c}{ Nation } & $\begin{array}{c}\text { Co2 reduction pledge / } \\
\text { \% of 2005 emissions }\end{array}$ & $\begin{array}{c}\text { Number of gigantic } \\
\text { solar plants needed } \\
\text { (Ouarzazate) }\end{array}$ & $\begin{array}{c}\text { Gigantic plants needed } \\
\text { for 40 \% reduction }\end{array}$ \\
\hline Algeria & $7-22$ & 8 & 50 \\
Egypt & none & 0 & 80 \\
Senegal & $5-21$ & 0,3 & 3 \\
Ivory Coast & $28-36^{1 \mathrm{v}}$ & 2 & 3 \\
Ghana & $15-45^{\text {1v }}$ & 1 & 3 \\
Angola & $35-50^{\text {1v }}$ & 6 & 7 \\
Kenya & $30^{1 \mathrm{v}}$ & 3 & 4 \\
Botswana & $17^{1 \mathrm{v}}$ & 1 & 2 \\
Zambia & $25-47^{1 \mathrm{v}}$ & 0,7 & 1 \\
South Africa & none & 0 & 190 \\
\hline
\end{tabular}

Note: i) The United States has pulled out of the deal; ii) No absolute target; iii) Pledge is above current level, no reduction; iv) Upper limit dependent on receiving financial support; v) EU joint pledge of $40 \%$ compared to 1990.

Table 4 shows the number of huge solar parks necessary for a few Asian countries.

Table 4. Number of Ouarzazate plants necessary for 40 per cent reduction in CO2s. (Note: Average of 250 - 300 days of sunshine was used for Kazakhstan, 300 - 350 days of sunshine per year for the others).

\begin{tabular}{|c|c|c|c|}
\hline Nation & $\begin{array}{c}\text { Co2 reduction } \\
\text { pledge / } \\
\% \text { of } 2005 \\
\text { emissions } \\
\end{array}$ & $\begin{array}{c}\text { Number of gigantic solar plants needed } \\
\text { (Ouarzazate) }\end{array}$ & $\begin{array}{c}\text { Gigantic plants needed for } 40 \% \\
\text { reduction }\end{array}$ \\
\hline $\begin{array}{l}\text { Saudi } \\
\text { Arabia }\end{array}$ & none $^{11}$ & 0 & 150 \\
\hline Iran & $4-12^{1 v}$ & 22 & 220 \\
\hline Kazakhstan & none $\mathrm{e}^{11}$ & 0 & 100 \\
\hline Turkey & 21 & 60 & 120 \\
\hline Thailand & $20-25^{1 \mathrm{v}}$ & 50 & 110 \\
\hline Malaysia & none $\mathrm{e}^{\mathrm{II}}$ & 0 & 80 \\
\hline Pakistan & none $^{11}$ & 0 & 60 \\
\hline Bangladesh & 3,45 & 2 & 18 \\
\hline
\end{tabular}

Note: i) The United States has pulled out of the deal; ii) No absolute target; iii) Pledge is above current level, no reduction; iv) Upper limit dependent on receiving financial support; v) EU joint pledge of $40 \%$ compared to 1990.

Given the economic advances in Asia, most countries need a lot of solar power parks for decarbonisation. The COP21 management would be able to help.

Finally, we come to the European scene. 
Table 5. Number of Ouarzazate plants necessary for 40 per cent reduction in CO2s (Note: Average of 250 - 300 days of sunshine per year was used)

\begin{tabular}{llrll}
\hline Nation & $\begin{array}{l}\text { Co2 } \\
\text { pledge / } \\
\begin{array}{l}\boldsymbol{\%} \\
\text { emissions }\end{array}\end{array}$ & $\mathbf{2 0 0 5}$ & $\begin{array}{l}\text { Number of gigantic solar plants needed } \\
\text { (Ouarzazate) }\end{array}$ & $\begin{array}{l}\text { Gigantic plants needed for 40 \% } \\
\text { reduction }\end{array}$ \\
\hline Germany & 49 & 550 & 450 \\
France & $37^{\mathrm{v}}$ & 210 & 220 \\
Italy & $35^{\mathrm{v}}$ & 230 & 270 \\
Sweden & $42^{\mathrm{v}}$ & 30 & 30 \\
\hline
\end{tabular}

Note: I) The United States has pulled out of the deal; ii) No absolute target; iii) Pledge is above current level, no reduction; iv) Upper limit dependent on receiving financial support; v) EU joint pledge of $40 \%$ compared to 1990.

The turn to renewables in Europe occur at the same time as atomic power stations are going to be closed, at least in some countries. Rational resilience? This makes solar power plants even more relevant, a coal power must be abolished, rather sooner than later. Other countries bet upon hydro power, but water is lost every year. Rational resilience? The US goes for natural gas, but fracking results in methane emissions. Rational resilience?

\section{Conclusion}

Time has come for halting and reducing $\mathrm{CO} 2$ emissions by real implementation and not Utopian dreams of a sustainable economy (Sachs, 2015). There is nothing to wait for any longer (Stern, 2015), as the COP23 must set up the promised Super Fund. No time for politicking in the UN any longer (Conca, 2015; Vogler, 2016). Time is tight with abrupt climate change.

It was hoped that the constant augmentation in CO2s would halt around 2015 and level off. But the new data for 2017 indicate that $\mathrm{CO} 2 \mathrm{~s}$ have started to increase again globally. This is very ominous, feeding global warming in the Arctic and the Antarctica. The culprit is as usual the rising energy consumption with heavy fossil fuel intensity - see Figure 13.

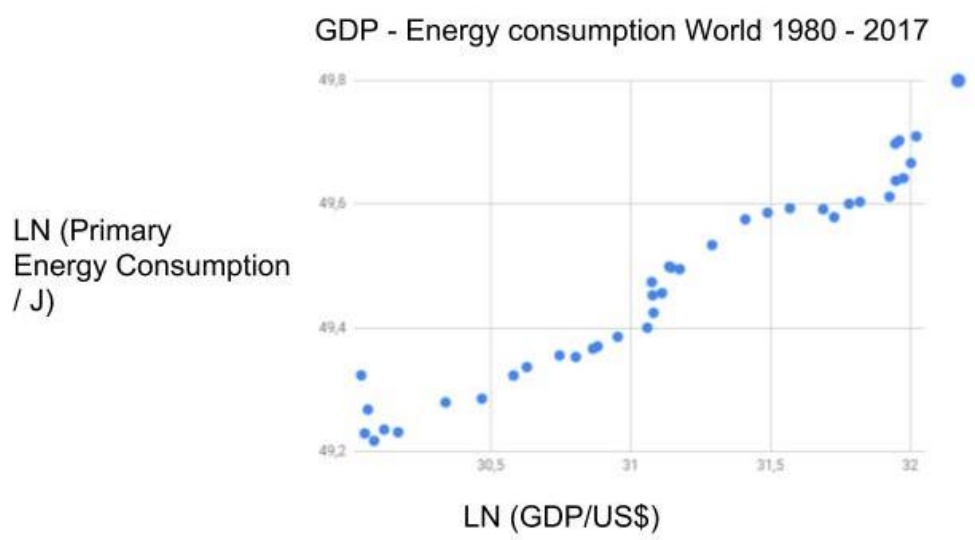

\section{References}

Figure 13. GDP and energy globally

Conka, K. (2015). Un Unfinished Foundation. The United Nations and Global Environmental Governance. Oxford: OUP.

Dutta, P. (1999) Strategies and Games. Cambridge, $\quad$ MA: $\quad$ MIT Press. .https://doi.org/10.1093/acprof:oso/9780190232856.001.0001

James, G. (1976). March and Johan P. Olsen, Ambiguity and Choice in Organizations. Bergen, Norway: Universitetsforlaget.

James, G. M., \& Herbert, A. S. (1993). Organizations. New York: Wiley, 1958. $2^{\text {nd }}$ (1999) ed., Oxford: Blackwell Publishers.

Paris. (2015). Tracking country climate pledges. Carbon Brief, https://www.carbonbrief.org/paris-2015-trackingcountry-climate-pledges

Pressman, J., \& Wildavsky, A. (1984). Implementation. Berkeley: University of California.

Ramesh, J. (2015). Green Signals: Ecology, Growth and Democracy in India (2015). Oxford: Oxford University Press. 
https://doi.org/10.1093/acprof:oso/9780199457526.001.0001

Sachs, J. D. (2015). The Age of Sustainable Development. New York: Columbia University Press. https://doi.org/10.7312/sach17314

Scott, B., Andrew, L., \& Richard, D. (2013). Theories of International Relations. Basingstoke: PalgraveMacmillan

Simon, H. (1957). Models of Man: Social and Rational- Mathematical Essays on Rational Human Behavior in a Social Setting. New York: Wiley.

Stern, N. (2007). The Economics of Climate Change. Oxford: OUP. https://doi.org/10.1017/CBO9780511817434

Stern, N. (2015). What are we waiting for? Cambridge, MA: MIT Press.

Vogler, J. (2016). Climate Change in World Politics. Basingstoke: Palgrave. https://doi.org/10.1057/9781137273413

\section{Appendix}

Solar power sources

EDGAR v 4.3.2, European Commission, Joint Research Centre (JRC)/PBL Netherlands Environmental Assessment Agency. Emission Database for Global Atmospheric Research (EDGAR), release version 4.3.2. http://edgar.jrc.ec.europe.eu, 2016 forthcoming

$\mathrm{CO} 2$ Emission Reduction With Solar

http://www.solarmango.com/in/tools/solar-carbon-emission-reduction

GDP sources:

World Bank national accounts data - data.worldbank.org

OECD National Accounts data files

GHG and energy sources:

World Resources Institute CAIT Climate Data Explorer - cait.wri.org

EU Joint Research Centre Emission Database for Global Atmospheric

Research - http://edgar.jrc.ec.europa.eu/overview.php

UN Framework Convention on Climate Change -

http://unfccc.int/ghg_data/ghg_data_unfccc/time_series_annex_i/items/3814.php

International Energy Agency. Paris.

Energy Information Administration. Washington, DC.

BP Energy Outlook 2016.

EU Emissions Database for Global Research EDGAR,

http://edgar.jrc.ec.europa.eu/

World Bank Data Indicators, data.worldbank.org

British Petroleum Statistical Review of World Energy 2016.

\section{Copyrights}

Copyright for this article is retained by the author(s), with first publication rights granted to the journal.

This is an open-access article distributed under the terms and conditions of the Creative Commons Attribution license which permits unrestricted use, distribution, and reproduction in any medium, provided the original work is properly cited. 